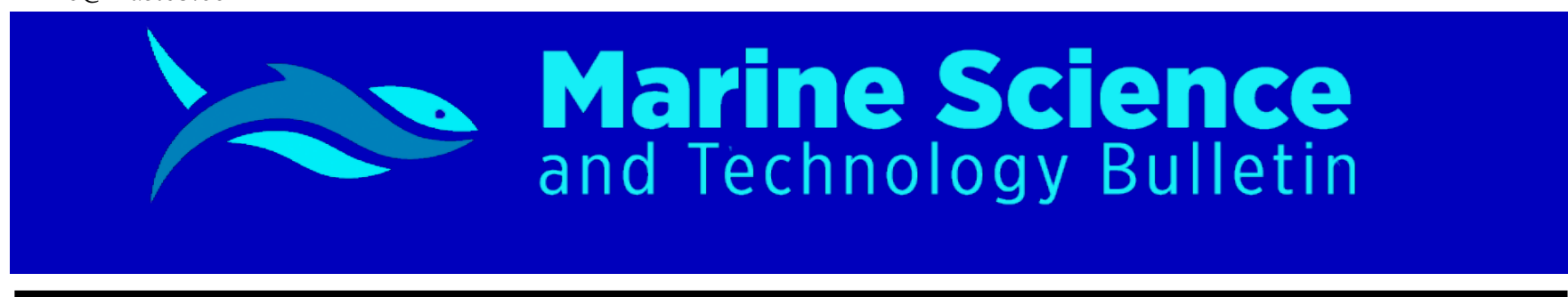

RESEARCH ARTICLE

\title{
Hierarchical flow among four shipping markets: An integrated approach for capesize shipping markets
}

\author{
Abdullah Açık $1^{*}$ (D) \\ ${ }^{1}$ Dokuz Eylül University, Maritime Faculty, Department of Maritime Business Administration, İzmir, Turkey
}

\begin{tabular}{|c|c|}
\hline ARTICLE INFO & A B S T R A C T \\
\hline $\begin{array}{l}\quad \text { Article History: } \\
\text { Received: } 11.08 .2020 \\
\text { Received in revised form: } 12.10 .2020 \\
\text { Accepted: } 08.12 .2020 \\
\text { Available online: } 18.12 .2020 \\
\text { Keywords: } \\
\text { Demolition market } \\
\text { Freight market } \\
\text { Hierarchical structure } \\
\text { Newbuilding market } \\
\text { Second-hand market }\end{array}$ & $\begin{array}{l}\text { Although there are theoretical researches on the interactions between four shipping sub- } \\
\text { markets, empirical studies examining four to cover are rare. Also, market interactions may differ } \\
\text { in positive or negative environments. Accordingly, the purpose of this study is to examine the } \\
\text { hierarchical structure among the } 4 \text { sub-maritime markets by providing a methodological } \\
\text { proposition. This study integrates the Interpretive Structural Modelling (ISM) method with the } \\
\text { asymmetric causality analysis and examines the hierarchical structure between the four markets } \\
\text { in terms of positive and negative shocks through the Capesize markets. The dataset used in the } \\
\text { study covers the period between } 07.01 .2013 \text { - } 18.07 .2019 \text { and consists of } 342 \text { weekly } \\
\text { observations. The results show that the hierarchical flow of positive and negative shocks differs } \\
\text { in the Capesize market. In terms of positive shocks, the demolition market stands out as the } \\
\text { starting point of the shocks, while in terms of negative shocks, freight and new building markets } \\
\text { come to the fore. Our study reveals hierarchical structures for maritime markets by testing their } \\
\text { relationships empirically and contributes to the maritime literature where the freight market is } \\
\text { theoretically considered a pioneer. A new methodical perspective is thought to be presented to } \\
\text { the maritime economics literature. }\end{array}$ \\
\hline
\end{tabular}

Please cite this paper as follows:

Açık, A. (2021). Hierarchical flow among four shipping markets: An integrated approach for capesize shipping markets. Marine

Science and Technology Bulletin, 10(1): 85-98.

\section{Introduction}

The maritime market is defined as having a derived demand structure (Branch, 2007), which can be explained as being directly affected by changes in demand for commodities and little control over the demand (McConville, 1999). Due to this structure, it is directly affected by the developments in the world economy (Stopford, 2009; Başer and Aç1k, 2019). Accelerations and slowdowns in economic activities are felt directly in the maritime market. For these reasons, the dry bulk freight market is defined as the leading indicator for the current situation of the world economy (Geman, 2009; UN, 2009; Tar1 and İnce, 2019) and future economic activities since it carries the raw materials for production activities (Lawson, 2008;

\footnotetext{
* Corresponding author

E-mail address: abdullah.acik@deu.edu.tr (A. Açık)
} 
Langdana, 2009; Şahin et al., 2018). It can be stated that the maritime market consists of four sub-markets; freight market, sale \& purchase market, newbuilding market, and demolition market (Beenstock and Vergottis, 1993; Stopford, 2009). These markets are in a very close relationship with each other. The freight and sell \& purchase markets are more dynamic than the others. Newbuilding and demolition markets, on the other hand, contribute to the formation of supply-demand balance by adjusting the carrying capacity in the market (Jugović et al., 2015). However, this balance is very difficult to form since there are too many independent players in the market. Due to the derived demand structure and the fact that there are too many players, there are continuous cycles in the maritime markets (Metaxas, 1988; Stopford, 2009), which are almost unlike each other. These cycles can also have serious returns and costs for cargo owners and ship owners.

Theoretically, the place where the action starts in the maritime markets is seen as the freight market. When the freight market booms, second-hand ship prices increase as current income and future income expectations for ship owners increase. Also, due to investors who want to increase their carrying capacity preferences by ordering new ships, the congestion of shipyards increases, and new ship prices increase. On the other hand, the number of ships sent to scrapping decreases as even old and obsolescence ships can carry out their commercial activities with sufficient profit in live market conditions. Therefore, the demolition prices offered by the scrap centers to the ships also increase. On the contrary, the drop in the freight market leads to a decrease in second-hand ship demand, causing prices to drop. As new orders decrease, new ship prices also drop, and as the number of ships going for scrapping increases, demolition prices also decrease.

Although the theoretical explanation of this current relationship is clear, there is no study as far as the authors know that empirically demonstrated their relationship by addressing the four markets together. In the literature, the relationships of these markets with each other and with some other variables are mostly examined. In this study, we aimed to combine the relations between the four markets on a single result by providing a methodological contribution. Also, considering that the spread of positive and negative shocks between the markets may be different, we also tried to model the two types separately. In our study, we examined the hierarchical relationship structure between the four markets over the Capesize market due to the data limitation. Firstly, we generated the relationship matrices with the asymmetric causality test developed by Hatemi-J (2012). The main reasons for using this method are that it can present relationships between shocks in four different combinations and detect nonlinear relationships between variables. Then, we formed hierarchical market models using these matrices as input in the ISM method. These models provide an important contribution in terms of empirically revealing the theoretical structure. It also reveals that the interaction between the markets has partially differentiated under positive and negative market conditions.

In the second section, we reviewed the studies on maritime markets and positioned our study by revealing its originality. In the third section, after introducing the methods we used in the research, we examined our data in the fourth section. In the fifth section, after presenting our results, we discussed and evaluated our findings.

\section{Literature Review}

The interactions between the maritime sub-markets are certain and therefore, the relationships between these markets are mostly examined in the literature. Also, these markets are exposed to external shocks such as fluctuations in international trade, fuel prices, shipbuilding costs, capital returns, and other factors (Beenstock and Vergottis, 1993). Therefore, studies examining the relations of these markets with some external factors are also included in the literature.

There are two approaches to the formation of freights, they can be described as traditional and modern (Efes et al., 2019). In the traditional approach, freights are formed by the balance between supply and demand (Beenstock and Vergottis, 1989). Freight rises or falls with any side dominating. Freight rates tend to increase if the demand for transportation is higher than transport capacity in the market, but if the transport capacity is higher, freights tend to decrease. Due to the shipbuilding period that takes time between 2-4 years (Tsolakis, 2005), the fact that the supply is inelastic (Koopmans, 1939) also contributes to the increase and variety in the freight cycles. For this reason, the only way to increase the supply in the short run can be provided by increasing the speed (Karakitsos and Varnavides, 2014). In the long run, balance can be achieved as new vessels enter the market (Lun et al., 2010). In the modern approach, the traditional model has been partially developed. In this model, the bargaining game is more prominent. Players can be identified as the owner of the cargo and the owner of the ship. According to current market conditions and future expectations, a player's bargaining power may be higher. The shipowner's bargaining power will be higher when the conditions in the freight market are good, but the cargo owner's power will be higher when the market conditions are bad. According to these conditions, the new freight rate is realized above or below the balance price and forms the new balance (Karakitsos and Varnavides, 2014). According to the general 
literature, the fluctuations in the economy are felt firstly in the freight market (Strandenes, 2012), as it is known as the place where the first reflection of the demand for maritime is felt. In a study in which the relationship with the economy was analyzed by Başer and Açı (2019) through GPD, it was found that the increases in GPD caused an increase in freight rates in the dry bulk market, but the situation changed slightly after the global crisis. A similar study was carried out by Efes et al. (2019). The authors modeled the dry bulk freight market by assuming China's foreign trade as demand for shipping and the global dry bulk fleet as supply-side for shipping. As a result, they supported the classical approach by concluding that the increase in trade volume affected the freight positively and the increase in the fleet negatively. Regardless of which approach for freights are used, the freights tend to return to the mean in the long run (Tvedt, 2003).

Entrepreneurs intending to second-hand ship purchases in the maritime market often have two purposes; increasing existing carrying capacity or being an asset player. Asset players hope to make a significant profit by trading at the right time (Kavussanos and Alizadeh, 2002). The factors that determine the second-hand value of a ship may be classified into two groups; vessel specific and market-specific. Vessel specific factors are size, type, age, general conditions, equipment, engine, etc., while market-specific ones are current and future income expectations of the owners (Alizadeh and Nomikos, 2009). Also, inflation may be considered as a market-specific factor (Stopford, 2009). The factors determining the secondhand value in the empirical literature were investigated by Pruyn et al. (2011). As a result, the authors found that the variables such as new building price, order book size, freight rates, fuel prices, age, and ship size were used extensively in second-hand ship price modeling. In the studies conducted in the literature, it was examined by Alizadeh and Nomikos (2003) whether the volume of second-hand sale \& purchase transactions had an effect on price volatility in the market. As a result, the authors found that the increase in the second-hand transaction volume caused the volatility in the prices of the ships to decrease. In terms of its relevance, the study conducted by Kavussanos (1997) found that the volatility in the prices of larger ships was higher.

The newbuilding market has an important role in the supply and demand balance by affecting the supply side (Stopford, 2009). If the supply amount in the market remains low and the freights are therefore too high, it offers new carrying capacity to the market, thus increasing the supply and ensuring that the freights reach a low level of equilibrium again. However, since shipbuilding takes a certain time, ordering a new ship is partly risky. As the orders are given according to current market conditions and expectations, the market is partially uncertain when the ordered ship is delivered (Tsolakis, 2005). In a study that empirically tested this situation, Başer and Açı (2018) examined the relationship between freights and ship tonnage delivered. According to their results, there is a positive relationship between the variables with a delay of 2 years. In other words, today's freight rate determines the tonnage delivered two years later and therefore determines the current order amount. As we mentioned earlier, the second-hand ship market can be expected to be more dynamic, as second-hand ships are available on the market and new ships are available after a certain period of orders. Adland and Jia (2015) tested this situation empirically in their study and found that new building prices were less volatile than second-hand ship prices. As an integrative study, factors affecting the volatility of new building prices have been studied by Dai et al. (2015). As a result of their empirical analysis, the authors found that the most essential part of the volatility in the new building prices was caused by freight rates. In another study examining the interaction between freight rate and ship value, the relationship between freight rate, second hand price and newbuilding ship price was examined by Açı and İnce (2019) considering their nonlinear structures. According to the results of the research, freight rate affects both second-hand price and newbuilding price for Capesize type ships. In addition, while an effect on freight rate was determined from second hand ship price, no effect on freight could be detected from the newbuilding price.

The ship demolition market plays a balancing role between supply and demand in the maritime market. When the supply surplus occurs in the market and the freight rates drop, a large number of ships are sent to demolition, and the freight rises again and reaches equilibrium as the supply quantity decreases (Buxton, 1991). Since the freight in the market directly affects ship demolition decisions, a negative relationship was expected to be found between them in the literature. This negative relationship was confirmed by Knapp et al. (2008). The authors found a negative relationship between the probability of the ship being sent for demolition and freight revenues. This was also indicated in the study carried out by Açık and Başer (2017). While the number of ships going for demolition at the high freight level decreases, it increases at the low freight level. In terms of the relation of the demolition price with the freight, when the freight rates increase, it can be expected that the demolition prices increase as the number of ships sent for scrapping decreases. This possible relationship was examined by Açık and Başer (2018) and the authors empirically confirmed the positive relationship between the variables. The authors stated that this relationship may be significant not only in terms of the maritime side but also in terms of demand for 
steel. Because high freight rates may be indicative of the active period of the economy, demand for steel may also be high. In this case, the demolition price offered to the ships may be high. Mikelis (2007) also evaluated that this relationship could be positive by statistical analysis. Undoubtedly, the price of demolition should be also related to variables other than maritime, because the steel from demolition is used as input to some sectors, such as the construction sector (Açı and Baran, 2019). Kagkarakis et al. (2016) examined the relationship between ship demolition prices and global scrap prices and found that global scrap prices are decisive for ship demolition prices since their small share in the global steel industry. The direct relationship between ship demolition prices and processed steel prices was analyzed by Tunç and Açık (2019) with panel data analysis method, and a significant causal relationship was found between steel prices and the demolition prices of the major ship demolition countries. To evaluate the studies on the demolition market in general, the market has a structure affected by both the freight market and the steel market, which makes its structure a bit complicated.

Studies mentioned in the literature are not limited to these and many more studies can be added. However, the studies mentioned understanding the general integrity of the subject is thought to be sufficient. As can be seen, the relations of the maritime markets among themselves or with the other external variables have been examined. Although theoretically the direction of the effects is explained as spreading to other markets starting from the freight market, there is no study that empirically demonstrates this by including all markets in a single methodology. In this study, we have divided the interactions as negative and positive and tried to put the interaction between the markets into a hierarchical structure. Thus, we wanted to test current theoretical knowledge empirically and understand whether the structure differs according to interaction type since positive and negative markets can produce different hierarchical relations.

\section{Methodology}

In the study, an integrated form of causality and ISM analysis is proposed as a method. With the asymmetric causality test developed by Hatemi-J (2012), causal relationships between 4 markets are examined. From these relationships, two separate matrices are generated with those from positive shocks to positive shocks and from negative shocks to negative shocks. These obtained matrices were used as input tables for ISM analysis and hierarchical structures were tried to be determined among the markets. Separate modeling of positive and negative shocks is to determine whether there is a difference in the spread of positive and negative shocks.

\section{Asymmetric Causality}

The asymmetric causality test is used to investigate the causality relationship between shocks in nonlinear time series in four different combinations; (i) from positive to positive, (ii) from positive to negative, (iii) from negative to negative, and (iv) from negative to positive. The method was developed by Hatemi-J (2012) and is a very functional method considering that players in the market can react differently depending on the type of shocks (news) whether it is good or bad information.

The method incorporates the idea underlying Toda and Yamamoto (1995) process and makes analyses by taking into account nonlinear effects (Shahbaz et al., 2017). The logic of the test is similar to the standard Granger (1969) causality, with the difference that the cumulative sums of positive and negative shocks are used to determine asymmetric causality (Tugcu and Topcu, 2018). Thus, it becomes possible to obtain results in four different combinations and to distinguish the causal impact of positive shocks from negative ones (Shahbaz et al., 2017).

Since the method is used in the analysis of nonlinear variables, possible autoregressive conditional heteroscedasticity (ARCH) effects on the variables should be considered (Tugcu et al., 2012). Therefore, Hatemi-J (2012) uses the bootstrap simulation technique to calculate critical values and Mwald statistics, and this provides more accurate critical values due to the leverage corrections (Hatemi-J and Uddin, 2012). Furthermore, the financial series are often far from the normal distribution as they are exposed to many unexpected events and shocks (Bildrici and Turkmen, 2015). The bootstrap simulation technique used in this method eliminates the necessity of normal distribution and provides a great advantage (Hatemi-J, 2012).

As the method follows Toda and Yamamoto (1995) process, the series do not have to be stationary, but the maximum degree of integration (dmax) needs to be determined (Umar and Dahalan, 2016). Unit root tests are used for this determination and if any unit root exists, the method is applied by adding extra lags to the estimated unrestricted VAR model (Hatemi-J and Uddin, 2012). For more detailed information, the study of Hatemi-J (2012) can be viewed.

\section{ISM Methodology}

The ISM method forms a hierarchical structure by prioritizing relationships of a complex system (Yudatama et al., 2018), which makes it possible to investigate directions of the relationships among these elements (Sage, 1977). Since the method takes into account the dependencies and driving forces among variables (Luthra et al., 2015), understanding macroscale relationships becomes possible (Chuang et al., 2013). 
In the first step of the method, a Structural Self-Interaction Matrix (SSIM) is formed that defines the relationships between the factors. These relationships are defined in 4 different combinations; There is an effect from factor a to factor $b$, there is an effect from factor $b$ to factor a, there is bidirectional interaction between factors a and $b$, and there is no interaction between factors $\mathrm{a}$ and $\mathrm{b}$. These relationships are represented by letters in the matrix;

- "V" for the one-way relationship from factor a to factor b;

- "A" for the one-way relationship from factor a to factor b;

- "X" for a bidirectional relationship between factors;

- and "O" for no relationship between factors.

Then, by converting the letters into numbers using the following rules, Initial Reachability Matrix (IRM) is obtained. The aim is to digitize the relations and make them ready for further steps;

- if $(a, b)$ in the SSIM equals to "V", $(a, b)$ equals to 1 and (b, a) equals to 0 ;

- if $(\mathrm{a}, \mathrm{b})$ in the SSIM equals to "A", $(\mathrm{a}, \mathrm{b})$ equals to 0 and (b, a) equals to 1 ;

- if $(a, b)$ in the SSIM equals to "X", $(a, b)$ equals to 1 and ( $b$, a) equals to 1 ;

- if $(\mathrm{a}, \mathrm{b})$ in the SSIM equals to "O", $(\mathrm{a}, \mathrm{b})$ equals to 0 and (b, a) equals to 0 .

Then, Final Reachability Matrix (FRM) is formed by obtaining "Dependence Power" with the sum of column values and "Driving Power" with the sum of rows for each variable. These values are determined to be used in MICMAC graph analysis to understand the position of variables in the complex system. For the ISM model, which presents the hierarchical structure, the IRM matrix is used. The affected factors by the variable are grouped as "Reachability" and the factors affecting it are grouped as Antecedent for each variable. "Intersection" set is obtained by the intersection of these two groups. The variable with the same "Reachability" and "Intersection" sets is positioned at the first level of the model. For other factors, positioning is completed in this way as well. In the MICMAC graph analysis, the factors are clustered in four different areas, which are "Independent", "Dependent", “Autonomous" and "Linkage". These groupings differ according to "Dependence" and "Driving" powers and make it easier to understand the positions of the variables in the complete system.

\section{Data}

The dataset used in the study covers the period between 07.01.2013-18.07.2019 and consists of 342 weekly observations. Representative variables were used for the four shipping markets due to the data access restriction. Freight variable refers to the Capesize route from Saldanha (South Africa) to Beilun (China) and the unit of it is freight paid \$ per ton. The second-hand variable refers to the value of the 5 years old Capesize ship and the unit of it is \$ million. Newbuilding variable refers to Capesize newbuilding price in China and the unit of it is $\$$ million. Lastly, the demolition variable refers to the Indian dry demolition price and the unit of it is \$ per ltd. Freight, second hand, and newbuilding variables are obtained from Bloomberg (2019) while demolition price is obtained from Athenian (2019). Descriptive statistics of the raw and return cases of the data used in the study are presented in Table 1. In the period discussed, signs of the skewness values of the return series indicated that negative shocks were more effective in demolition prices while positive shocks were more effective in the other three markets. The fact that the kurtosis values of the return series of the 3 markets are very high compared to the freight is due to the fewer changes. Since weekly data is used, weekly changes are less in the 3 markets and this causes the return values to be concentrated at 0 . Fortunately, our analysis uses the method based on the Toda and Yamamoto (1995) approach and it does not require a condition of stationarity.

Table 1. Descriptive statistics of the variables

\begin{tabular}{lcccccccc}
\hline & Freight & Second Hand & Newbuilding & Demolition & RFR & RSH & RNB & RDEM \\
\hline Mean & 11.62 & 33.33 & 46.88 & 374.78 & 0.001 & 0.000 & 0.000 & -0.000 \\
Median & 12.08 & 33.00 & 46.00 & 395.00 & 0.000 & 0.000 & 0.000 & 0.000 \\
Maximum & 22.98 & 52.00 & 56.50 & 465.00 & 0.326 & 0.162 & 0.064 & 0.083 \\
Minimum & 4.00 & 21.00 & 40.00 & 225.00 & -0.247 & -0.103 & -0.056 & -0.096 \\
Std. Dev. & 3.92 & 7.40 & 4.65 & 63.35 & 0.07 & 0.02 & 0.00 & 0.02 \\
Skewness & 0.27 & 0.46 & 0.44 & -0.72 & 0.08 & 1.50 & 1.78 & -0.41 \\
Kurtosis & 2.76 & 2.97 & 2.14 & 2.26 & 4.74 & 18.13 & 25.40 & 6.39 \\
J-Bera & 5.16 & 12.44 & 21.65 & 37.40 & 43.4 & 3382.5 & 7312.6 & 173.2 \\
Prob. & 0.07 & 0.00 & 0.00 & 0.00 & 0.000 & 0.00 & 0.00 & 0.00 \\
Obs. & 342 & 342 & 342 & 342 & 341 & 341 & 341 & 341 \\
\hline
\end{tabular}

Source: Bloomberg (2019); Athenian (2019). 


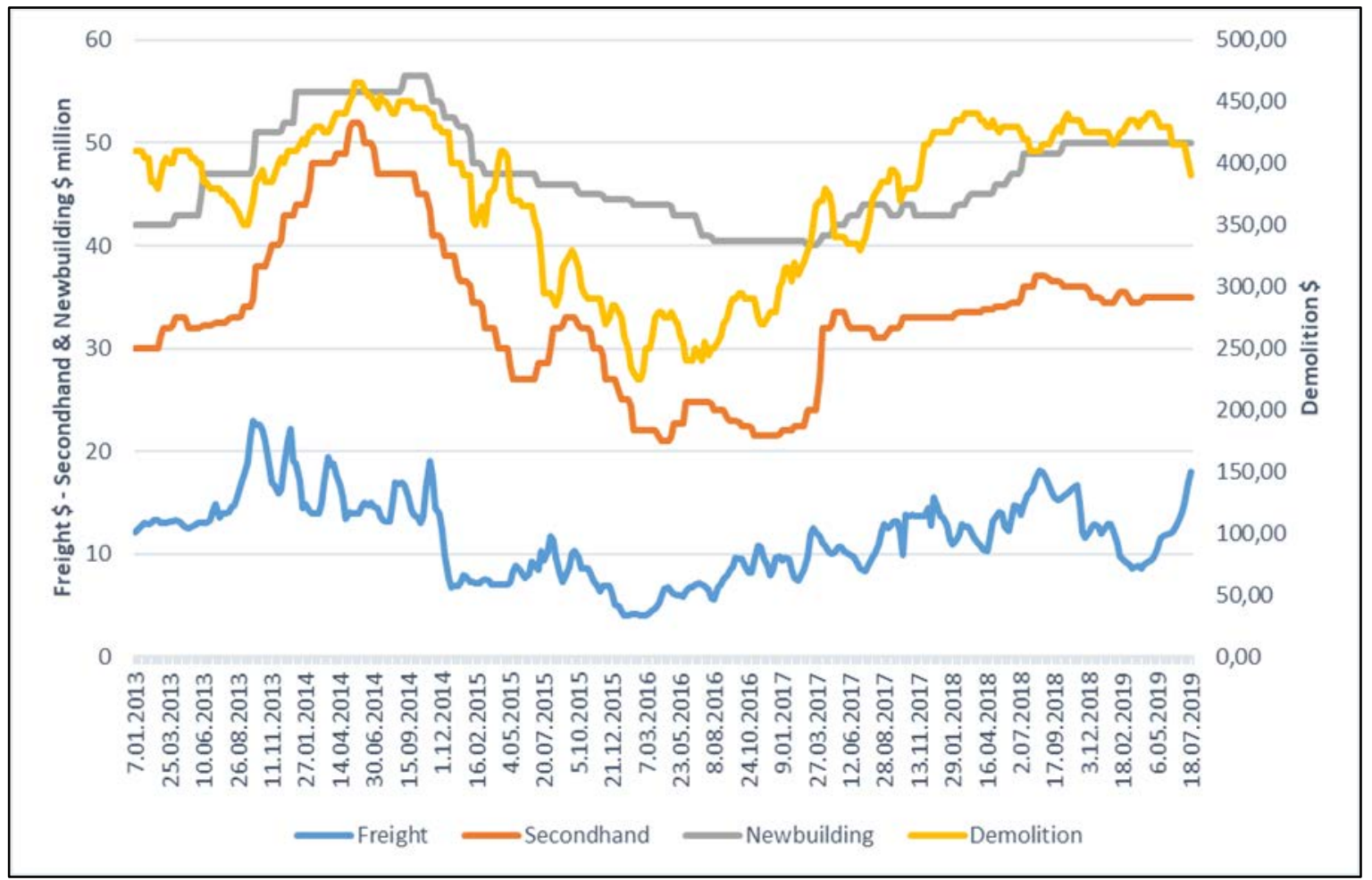

Figure 1. Graphical display of the variables (Source: Bloomberg (2019); Athenian (2019))

The visual of the variables used in the study is presented in Figure 1. It can be said that there is a high correlation between the second-hand and demolition values. The new building prices are inherently more stable. The fact that the ship delivery process is partially long and the market is not known when the ship is received causes the prices to be less volatile. Freight also similarly moves around a certain average but with partially high volatility. It can also be said that there are structural breaks both in the value of second-hand ships and in the demolition prices. For this reason, it is important to apply unit root tests that take into account breaks in level and trend. Standard tests may offer a result that they include unit root as they do not take into account possible structural breaks.

\section{Results}

In this section, firstly, unit root, and linearity tests, which are necessary for the asymmetric causality test, are applied. According to the results obtained from these tests, asymmetric causality test is applied. Then, two separate ISM models are constructed using the asymmetric causality test results related to the positive-positive and negative-negative analysis.

\section{Unit Root Test Results}

To determine the maximum degree of integration in the asymmetric causality analysis, root unit tests with structural breaks were applied to the series and the results are presented in Table 2. One break ADF test (Zivot and Andrews, 1992), one break LM test (Lee and Strazicich, 2013), two break ADF test (Narayan and Popp, 2010), and two break LM test (Lee and Strazicich, 2003) were applied to all series. The maximum lag length was determined as 25 and AICc was used to determine the most suitable lag. According to the results obtained, considering the structural breaks of the variables in the level and level \& trend, the null of the unit root hypothesis is rejected with at least one test for all variables used in the analyzes. In this case, the maximum degree of integration value is determined as 0 for all asymmetric analysis combinations.

\section{Linearity Test Results}

As the asymmetric causality test used in the study is a nonlinear method, the linearity of the series should be tested. For this reason, all the variables were first converted to the return series, and then the most suitable ARMA models were estimated. After checking the significance and roots of the estimated models, BDS Independence (Brock et al., 1987) and ARCH (Engle, 1982) tests were applied to their residuals. The results of the applied tests were presented in Table 3. The obtained results indicated that the null of the linearity hypothesis was rejected for all variables. In this case, the applicability of the asymmetric causality test is confirmed.

The fact that the structures of the variables are not linear is an indicator that the parameters have changed over time. Unexpected shocks and structural breaks in the global world disrupt the structure of the series. The main reason for this may be the derived demand structure of the maritime markets. 
Table 2. Unit root tests with structural breaks for capesize freight market

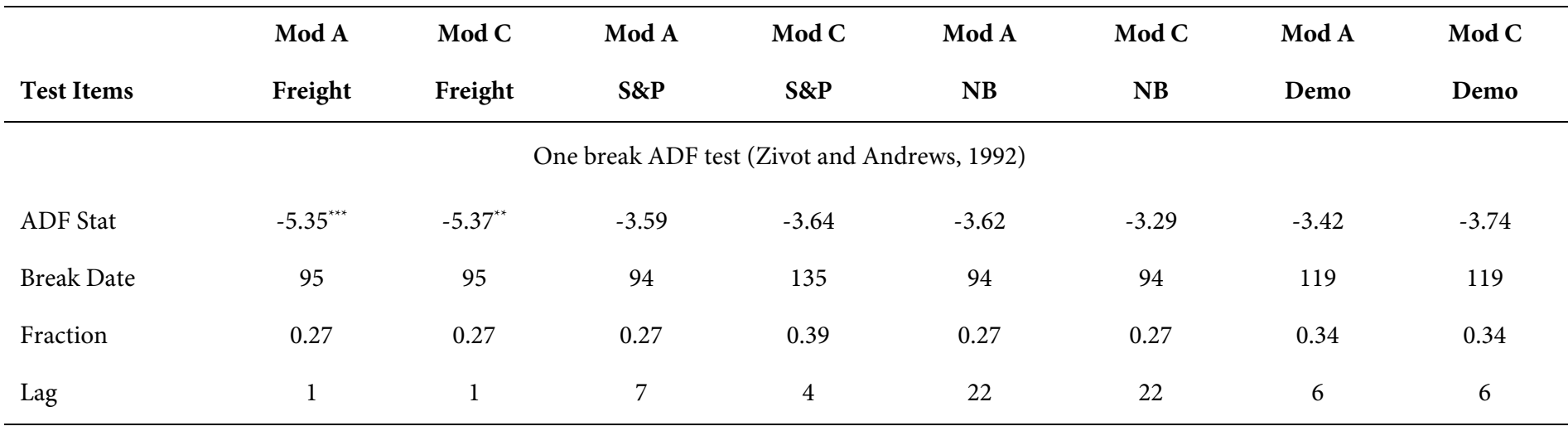

One break LM test (Lee and Strazicich, 2013)

\begin{tabular}{lcccccccc} 
LM Stat & -2.84 & $-4.35^{*}$ & -2.02 & -2.74 & -1.90 & -2.25 & -1.52 & -2.48 \\
Break Date & 97 & 114 & 221 & 134 & 87 & 129 & 132 & 0.54 \\
Fraction & 0.28 & 0.33 & 0.64 & 0.39 & 0.25 & 0.37 & 0.38 \\
Lag & 1 & 1 & 4 & 4 & 22 & 22 & 6 \\
\hline
\end{tabular}

Two break ADF test (Narayan and Popp, 2010)

\begin{tabular}{|c|c|c|c|c|c|c|c|c|}
\hline ADF Stat & $-6.01^{* * *}$ & $-6.35^{* * *}$ & $-4.68^{* *}$ & $-5.72^{\star * *}$ & $-4.58^{\star *}$ & $-6.05^{\star * *}$ & $-4.79^{* *}$ & -4.03 \\
\hline Break Date & 95,141 & 95,187 & 90,142 & 90,216 & 94,172 & 37,181 & 118,226 & 128,289 \\
\hline Fraction & $0.27,0.41$ & $0.27,0.54$ & $0.26,0.41$ & $0.26,0.63$ & $0.27,0.50$ & $0.10,0.52$ & $0.34,0.66$ & $0.37,0.84$ \\
\hline Lag & 1 & 1 & 7 & 7 & 22 & 22 & 6 & 6 \\
\hline \multicolumn{9}{|c|}{ Two break LM test (Lee and Strazicich, 2003) } \\
\hline LM Stat & -3.12 & $-5.54^{*}$ & -2.20 & -4.62 & -2.06 & -4.40 & -1.93 & -3.97 \\
\hline Break Date & 97,101 & 95,194 & 182,226 & 90,221 & 87,243 & 94,220 & 109,220 & 128,212 \\
\hline Fraction & $0.28,0.29$ & $0.27,0.56$ & $0.53,0.66$ & $0.26,0.64$ & $0.25,0.71$ & $0.27,0.64$ & $0.31,0.64$ & $0.37,0.62$ \\
\hline Lag & 1 & 1 & 4 & 4 & 22 & 22 & 6 & 6 \\
\hline
\end{tabular}

Note: Mod A refers to break in level, Mod C refers to break in level and trend. $\mathrm{H}_{0}$ rejected ${ }^{* * *} 99 \%,{ }^{* *} 95 \%,{ }^{*} 90 \%$.

\section{Causality Test Results}

The asymmetric causality analysis was applied between positive shocks and between negative shocks. The maximum integration degree is determined as 0 , the maximum number of lags is selected as 25 , and the optimum lag selection criterion is selected as AICc. The causality results among positive shocks are shown in Table 4. According to the results obtained, positive shocks in freights are the cause of positive shocks in secondhand ship value. Positive shocks in second-hand ship value are the cause of positive shocks in new ship value. Finally, positive shocks in demolition prices are the cause of positive shocks in freights.
Results between negative shocks are presented in Table 5 . Unlike positive shocks, much more significant relationships were found in negative results. According to the results obtained, negative shocks in freights are the causes of negative shocks in second-hand ship value, new ship value, and demolition prices. Negative shocks in second-hand ship value are the causes of negative shocks in demolition prices. Negative shocks in the value of the new ship are the causes of negative shocks in freights and demolition prices. Finally, negative shocks in demolition prices are the causes of negative shocks in second-hand ship value. 
Table 3. Linearity test results

\begin{tabular}{ccccc}
\hline Dimension & Freight & Secondhand & Newbuilding & Demolition \\
\hline $\mathbf{2}$ & $6.450^{* * *}$ & $3.918^{* * *}$ & $5.219^{* * *}$ & $4.178^{* * *}$ \\
$\mathbf{3}$ & $6.550^{* * *}$ & $2.427^{* *}$ & $3.897^{* * *}$ & $4.481^{* * *}$ \\
$\mathbf{4}$ & $6.834^{* * *}$ & $1.719^{*}$ & $3.261^{* * *}$ & $5.312^{* * *}$ \\
$\mathbf{5}$ & $6.948^{* * *}$ & $2.650^{* * *}$ & $3.744^{* * *}$ & $5.957^{* * *}$ \\
$\mathbf{6}$ & $7.047^{* * *}$ & $3.558^{* * *}$ & $3.897^{* * *}$ & $6.915^{* * *}$ \\
\hline ARCH & $41.06^{* * *}$ & $65.01^{* * *}$ & $5.99^{* *}$ & $-5.26^{* *}$ \\
\hline ARMA (p, q) & $(12,12)$ & $(8,2)$ & $(11,9)$ & $(8,8)$ \\
AIC & -2.56 & -5.11 & -6.78 & -4.87 \\
\hline
\end{tabular}

Note: Null of linearity is rejected at ${ }^{* * *} 1 \%,{ }^{* *} 5 \%,{ }^{*} 10 \%$.

Table 4. Causality test results related positive shocks

TO

Freight Secondhand Newbuilding Demolition

\begin{tabular}{llcccc}
\hline & Freight & $\mathrm{X}$ & $34.957^{* * *}$ & 7.097 & 6.729 \\
$\underset{\mathrm{J}}{\mathrm{O}}$ Secondhand & 5.417 & $\mathrm{X}$ & $13.245^{* *}$ & 1.664 \\
$\underset{\mathrm{T}}{\mathrm{I}}$ & Newbuilding & 0.962 & 3.964 & $\mathrm{X}$ & 0.380 \\
& Demolition & $8.546^{* *}$ & 3.042 & 0.261 & $\mathrm{X}$ \\
\hline
\end{tabular}

Note: Null of noncausality is rejected at ${ }^{* * *} 1 \%,{ }^{* *} 5 \%,{ }^{*} 10 \%$.

Table 5. Causality test results related negative shocks

\section{TO}

\begin{tabular}{|c|c|c|c|c|c|}
\hline & & Freight & Secondhand & Newbuilding & Demolition \\
\hline \multirow{4}{*}{ 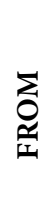 } & Freight & $\mathrm{X}$ & $34.957^{* * *}$ & 7.097 & 6.729 \\
\hline & Secondhand & 5.417 & $\mathrm{X}$ & $13.245^{* *}$ & 1.664 \\
\hline & Newbuilding & 0.962 & 3.964 & $\mathrm{X}$ & 0.380 \\
\hline & Demolition & $8.546^{* *}$ & 3.042 & 0.261 & $\mathrm{X}$ \\
\hline
\end{tabular}

Note: Null of noncausality is rejected at ${ }^{* *} 1 \%,{ }^{* *} 5 \%,{ }^{*} 10 \%$.

After the asymmetric causality analysis, ISM analyzes are applied based on the results obtained. Two separate ISM analyzes are applied for positive and negative shocks in the Capesize markets.

\section{ISM Results}

Considering the results obtained from the asymmetric causality test, two separate ISM analyzes were applied for both positive and negative shocks. Thus, it was tried to be determined whether the hierarchical structure of positive and negative interactions changed in different market conditions.

\section{Positive Shocks Related Results}

Based on the rules applied in ISM analysis with the matrix presenting the relationship between the positive shocks in Table
4, Structural self-interaction matrix (SSIM) was formed and presented in Table 6.

Table 6. Structural self-interaction matrix (SSIM)

\begin{tabular}{lcccc}
\hline & Freight & Secondhand & Newbuilding & Demolition \\
\hline Freight & $\mathrm{V}$ & $\mathrm{X}$ & $\mathrm{A}$ \\
Secondhand & & & $\mathrm{V}$ & $\mathrm{X}$ \\
Newbuilding & & & & $\mathrm{X}$ \\
Demolition & & &
\end{tabular}

The initial and final reachability matrix was generated through the letterings in Table 6 and presented in Table 7. This table also includes the driver and dependence powers of the markets. The interpretation of these forces is made clearer in the MICMAC analysis section.

Using the matrix in Table 7, Table 8, which will be used in leveling, was obtained. In this table, all levels are determined so that the markets with the same values in the reachability and intersection columns are at the first level. Accordingly, demolition is at level 4, freight at level 3, second hand at level 2, and newbuilding at level 1 . With these level setting values, a visual ISM model was formed.

The ISM model, which examines the spillover of positive shocks in the Capesize market hierarchically, is presented in Figure 2. According to this model, 4 maritime markets are located at 4 different levels. The demolition market located at the bottom is in a position that affects and is not affected by all other markets, which indicates that positive shocks spillover from the demolition market to other markets. The freight market, which is located at level 3, transmits the shocks it receives from the demolition market to other markets through the sale \& purchase market. The sale \& purchase market transmits the positive shock it receives from the demolition and freight markets to the newbuilding market. The new building market is affected by three other markets, but it cannot affect any other market.

LEVEL 1<smiles>CC(C)C</smiles>

LEVEL 2<smiles>CCC(C)C</smiles>

LEVEL 3<smiles>CCC(C)C</smiles>

LEVEL 4

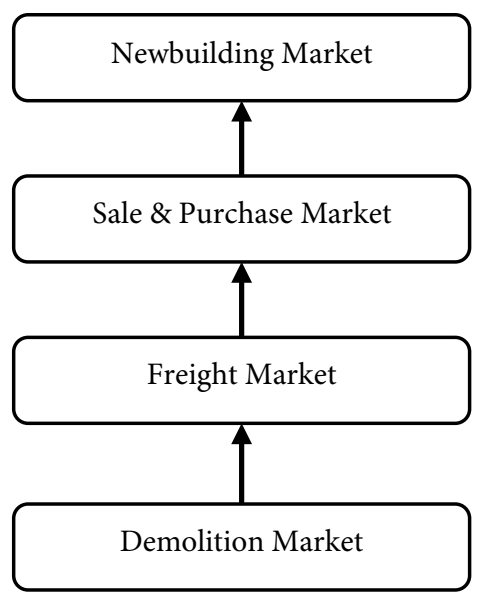

Figure 2. ISM results 
Table 7. Initial and final reachability matrix

\begin{tabular}{lccccc}
\hline & Freight & Secondhand & Newbuilding & Demolition & DRIVER \\
\hline Freight & 1 & 1 & 0 & 0 & 0 \\
Secondhand & 0 & 1 & 1 & 1 & 0 \\
Newbuilding & 0 & 0 & 0 & 1 & 1 \\
Demolition & 1 & 0 & 2 & 1 \\
DEPENDENCE & 2 & 2 & & \\
\hline
\end{tabular}

Table 8. Use of reachability matrix in level setting

\begin{tabular}{llcccc}
\hline & & Reachability & Antecedent & Intersection & Level \\
\hline $\mathbf{1}$ & Freight & 1,2 & 1,4 & 1 \\
$\mathbf{2}$ & Secondhand & 2,3 & 1,2 & 2 \\
$\mathbf{3}$ & Newbuilding & 3 & 2,3 & 3 \\
$\mathbf{4}$ & Demolition & 1,4 & 4 & 4 \\
\hline
\end{tabular}

The MICMAC graphic analysis based on the values in Table 8 is presented in Figure 3. This analysis shows how markets are positioned regarding positive shocks. However, since there are few variables (markets) in the analysis, they are located in border regions. Based on the ISM model in Figure 2, it can be said that the Demolition variable is included in the Independent cluster since it is in a position that affects all markets. It can be said that the freight and sale \& purchase markets are included in the Linkage cluster, as they transfer the positive shocks they receive to the Newbuilding market. Finally, the Newbuilding market can be said to be in the Dependent cluster, because this market is at the top of the ISM model and does not affect any other market.

\section{Negative Shocks Related Results}

Based on the matrix showing the relationship between the negative shocks presented in Table 5, the Structural SelfInteraction Matrix (SSIM) in Table 9 was generated.

The letters in SSIM were digitized according to the ISM methodology, and the Initial and Final Reachability Matrix in Table 10 were obtained. It can be said that the values of Driver and Dependence powers obtained in this matrix vary more than those in positive shocks. In MICMAC graphic analysis, this variety can make it possible to interpret better.

Level determination processes for each market using the values in Table 10 are presented in Table 11. According to this transaction, while second hand and demolition markets are positioned at the 1 st level, freight and newbuilding markets are positioned at the 2 nd level.

The ISM model formed after the leveling process is presented in Figure 4. According to this model, while the freight and new building markets are positioned at the 2nd level, the sale \& purchase and demolition markets are positioned at the 1 st level. This shows that negative shocks are reflected from freight and new building markets to other markets. The markets where negative shocks have ended were identified as sale \& purchase and demolition markets.

Markets are positioned again on the borders as the number of variables is low in the MICMAC graph analysis. However, when cluster determination is applied with the help of the ISM model, Newbuilding and Freight markets can be said to be in the Independent cluster since these markets are the sources of negative shocks. On the other hand, it can be said that the demolition and sales \& purchase markets are in the Dependent cluster since these markets receive negative shocks from other markets.

\section{Discussion}

In this study, firstly, the price information of the variables that make up the 4 main maritime markets of Capesize shipping is considered as representative values. For instance, freight refers to Capesize route from Saldanha (South Africa) to Beilun (China), the second-hand variable refers to the value of the 5 years old Capesize ship, the newbuilding variable refers to Capesize newbuilding price in China, and the demolition variable refers to Indian dry demolition price. Therefore, defining the relationship between them may not be very confident, but it is believed that reasonable results have been obtained in these current conditions related to the data limitation. 
Table 9. Structural self-interaction matrix (SSIM)

\begin{tabular}{|c|c|c|c|c|}
\hline & Freight & Secondhand & Newbuilding & Demolition \\
\hline Freight & & $\mathrm{V}$ & $\mathrm{X}$ & A \\
\hline Secondhand & & & $\mathrm{V}$ & $\mathrm{X}$ \\
\hline Newbuilding & & & & $\mathrm{X}$ \\
\hline Demolition & & & & \\
\hline
\end{tabular}

Table 10. Initial and final reachability matrix

\begin{tabular}{llllcc}
\hline & Freight & Secondhand & Newbuilding & Demolition & DRIVER \\
\hline Freight & 1 & 1 & 1 & 1 & 4 \\
Secondhand & 0 & 1 & 0 & 1 & 1 \\
Newbuilding & 1 & 0 & 0 & 1 & 2 \\
Demolition & 0 & 1 & 2 & 4 & \\
DEPENDENCE & 2 & 3 &
\end{tabular}

Table 11. Use of reachability matrix in level setting

\begin{tabular}{lllllc}
\hline & Reachability & Antecedent & Intersection & Level \\
\hline $\mathbf{1}$ & Freight & $1,2,3,4$ & 1,3 & 1,3 & 2 \\
$\mathbf{2}$ & Secondhand & 2,4 & $1,2,4$ & 2,4 & 1 \\
$\mathbf{3}$ & Newbuilding & $1,3,4$ & 1,3 & 1,3 & 2 \\
$\mathbf{4}$ & Demolition & 2,4 & $1,2,3,4$ & 2,4 & 1 \\
\hline
\end{tabular}

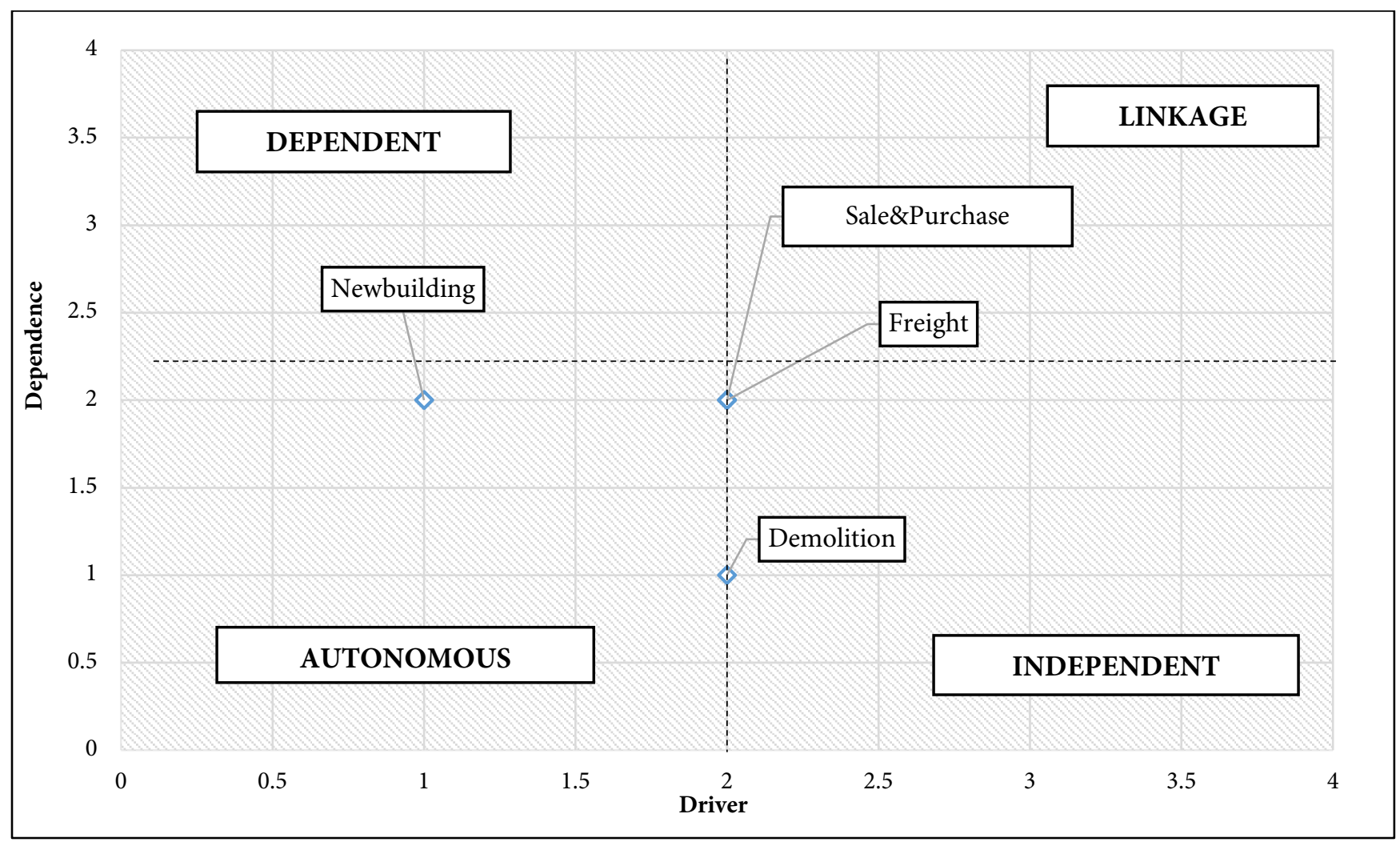

Figure 3. MICMAC analysis 


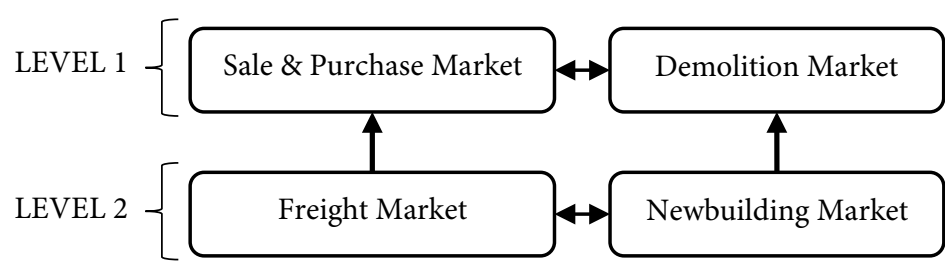

Figure 4. ISM results

The ISM model obtained related to the hierarchical flow of positive shocks is quite compatible with the theoretical structure. The location of markets other than the Demolition market is generally in line with the accepted approach in the literature. The increases in the freight market cause an increase in the value of second-hand ships, as the current income and future income expectations increase (Alizadeh and Nomikos, 2009; Pruyn et al., 2011; Açık and İnce, 2019). Also, as the demand for new ships increases in this buoyant market environment, there is a positive flow from second-hand ship prices to new ship prices. Considering that, the price of the new ship is affected by the volatility in the freight (Dai et al., 2015), and it is less volatile than the price of the second ship (Adland and Jia, 2015), the position of it in the model is reasonable. The position of demolition prices in the model does not seem very reasonable in the maritime market at first glance. However, considering the relationship between demolition prices and economic activities, a reasonable explanation can be made. Because ship demolition prices are closely related to steel prices
(Tunç and Açık, 2019) and the increase in steel prices often causes an increase in demolition prices. Also, an increase is observed in demolition prices as the ship going to dismantling decreases in live market conditions. The increase in steel prices is experienced in times when the economy is alive considering the widespread use of steel in the global industries. Therefore, positive shocks from demolition prices can be considered as an indicator of economic recovery. As the demand for maritime transportation with derived demand structure increases as a result of the increase in economic activities, firstly, there is a positive reflection on freights. This positive relationship between demolition price and freight rates was also confirmed empirically in the literature (Açık and Başer, 2018).

On the other hand, the fact that the freight and the new building markets are at the 2 nd level in the structure related to negative shocks do not partially comply with the evaluation regarding the positive shocks. Assuming that the demolition market represents the world economy, negative shocks could be expected to start from this market. The fact that freights are at the second level is reasonable. Negative shocks in freights are transferred to the sale \& purchase market since it is related to the current and future income expectations (Alizadeh and Nomikos, 2009; Pruyn et al., 2011; Açık and İnce, 2019). Also, it is reasonable to see a decrease in the demolition market due to the falling ship values and the increasing ship amount sent to the scrapping (Knapp et al., 2008; Açık and Başer, 2017).

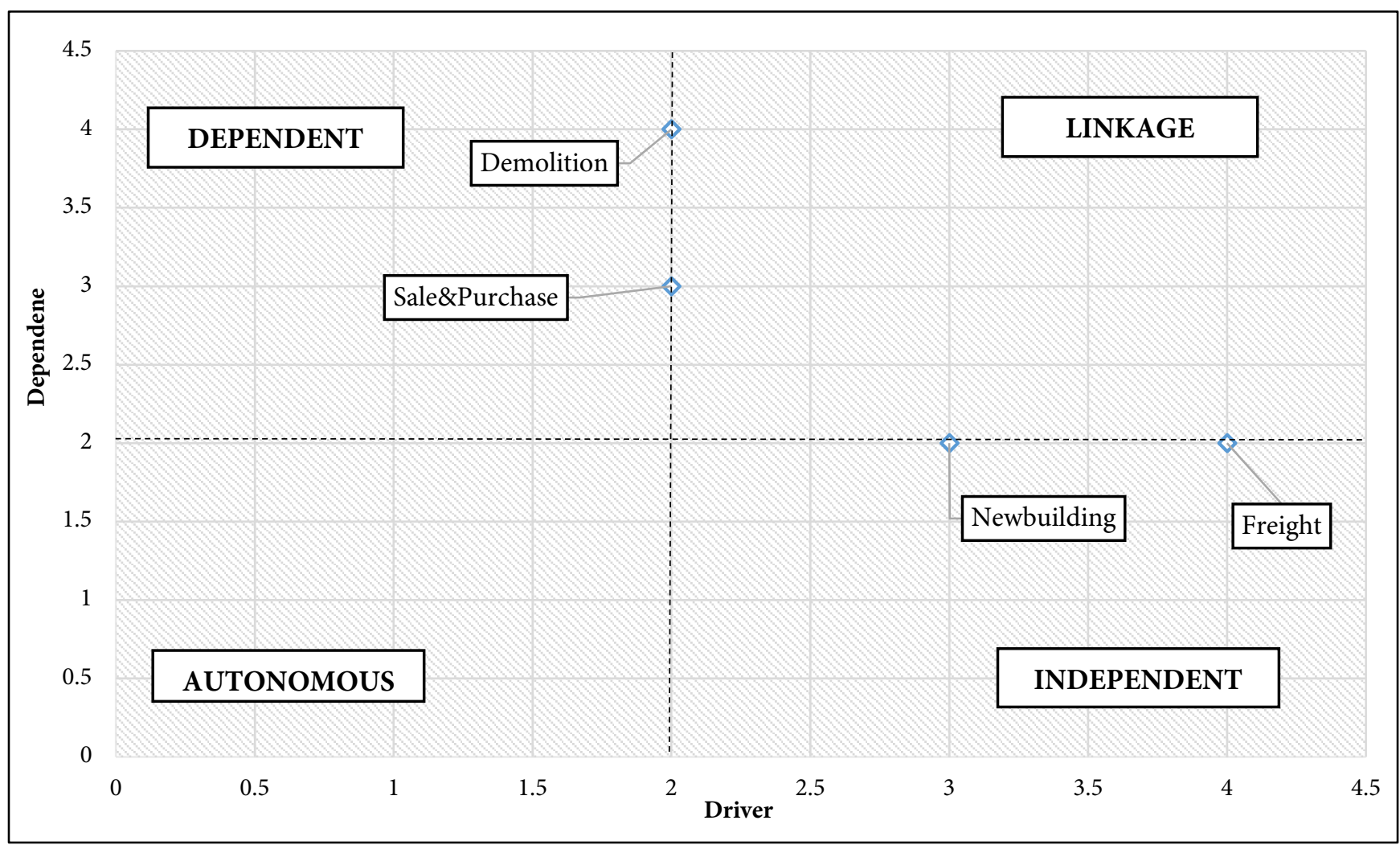

Figure 5. MICMAC analysis 
The reason why the new building market is at the 2 nd level may be related to the role of sentiment in ship orders because one of the most important factors affecting ship investors' decisions is their sentiment related to the economic environment (Stopford, 2009). Therefore, the declining new order demand may be causing a drop in price, and such negative shocks may be spreading to other markets. Of course, this study is evaluated within the maritime markets. There are also many macro variables that affect the shipping market such as interest rates, commodity prices, exchange rates, etc., and these are the main sources of the shocks. Therefore, analyzes including such variables can provide more comprehensive results.

\section{Conclusion}

We aimed to conduct research examining the hierarchical structure of freight, sale \& purchase, newbuilding and demolition markets, which are accepted as the 4 sub-markets of the maritime market, in a single model. There are studies in the literature that examine the relationships between these markets and some other external variables. However, as far as the authors know, there is no study examining a hierarchical structure by considering all of them in a single model. In this respect, it is considered that this research applied to the Capesize market has made an original contribution. In our study, we also provided a methodological contribution by integrating the two models and by examining the relationships in two separate structures, positive and negative. The ISM model makes it possible to determine the hierarchical structure and priority order of the elements in a complex system. The asymmetric causality test is a method that examines nonlinear causality relationships through shocks that variables contain. Based on the classical maritime market view, we wanted to demonstrate empirically that shocks coming to the maritime market spread to the freight market first and then to other markets. We determined that the models that emerged as a result of the research differed according to the positive and negative shocks and the hierarchies of the structures changed. We have linked the reason for the demolition market to come to the fore in the positive model, not just to be dependent on the shipping market and to be closely related to economic activities.

As a limitation of the study, it can be stated that the Capesize type is used and limited the scope of the research. The results may be more generalizable if analysis can be applied for other types of ships or if common value indices can be developed for all ships. Also, contrary to the classical view that examines the maritime markets in themselves, other important macro variables, such as interest rates, exchange rates, commodity prices, can be added to the models based on the modern view that relates it to other macro variables.

\section{Compliance with Ethical Standards}

\section{Conflict of Interest}

The author declares that there is no conflict of interest.

\section{Ethical Approval}

For this type of study, formal consent is not required.

\section{References}

Açık, A. \& Baran, E. (2019). The reflection of ship demolition prices to construction costs in Turkey. Marine Science and Technology Bulletin, 8(1): 23-29. https://doi.org/10.33714/masteb.547103

Açık, A. \& Başer, S. Ö. (2018). The relationship between freight rates and demolition prices. Uluslararası Ticaret ve Ekonomi Araştırmaları Dergisi, 2(1): 16-32. https://doi.org/10.30784/epfad.363721

Açık, A. \& Başer, S. Ö. (2017). The relationship between freight revenues and vessel disposal decisions. Journal of Research in Economics, Politics \& Finance, 2(2): 96-112. https://doi.org/10.30784/epfad.363721

Açık, A. \& İnce, M. R. (2019). Income and asset value relationship: A nonlinear approach to Capesize shipping market (pp. 35-43). In Koc, S., Yilmaz Genc, S., Benli, V.H. (Eds.), Economic Issues: Global and Local Perspectives. London: Cambridge International Academics. 196p.

Adland, R. \& Jia, H. (2015). Shipping market integration: The case of sticky new building prices. Maritime Economics \& Logistics, 17(4): 389-398. https://doi.org/10.1057/ mel.2014.35

Alizadeh, A. H. \& Nomikos, N. K. (2003). The price-volume relationship in the sale and purchase market for dry bulk vessels. Maritime Policy \& Management, 30(4): 321-337. https://doi.org/10.1080/0308883032000145627

Alizadeh, A. \& Nomikos, N. (2009). Shipping Derivatives and Risk Management. London: Palgrave. 527p.

Athenian, S. A. (2019). Weekly demolition report. Retrieved on August 5, 2019 from https://www.atheniansa.gr.

Başer, S. Ö. \& Açık, A. (2019). The effects of global economic growth on dry bulk freight rates. Uluslararası Ticaret ve Ekonomi Araştırmaları Dergisi, 3(1): 1-17. https://doi.org/10.30711/utead.507566 
Başer, S. Ö. \& Açık, A. (2018). The response of shipbuilding activities to freight market. International Journal of Economics and Administrative Sciences, 4(1): 120-136. https://doi.org/10.29131/uiibd.415303

Beenstock, M. \& Vergottis, A. (1993). Econometric Modelling of World Shipping. Netherlands: Springer. 254p.

Beenstock, M. \& Vergottis, A. (1989). An econometric model of the world market for dry cargo freight and shipping. Applied Economics, 21(3): 339-356. https://doi.org/ $\underline{10.1080 / 758522551}$

Bildirici, M. E. \& Turkmen, C. (2015). Nonlinear causality between oil and precious metals. Resources Policy, 46(2): 202-211. https://doi.org/10.1016/j.resourpol.2015.09. $\underline{002}$

Bloomberg (2019). Freight, Second hand, Newbuilding Values $\begin{array}{llll}\text { Retrieved on } & \text { August }\end{array}$ https://www.bloomberg.com/professional

Branch, A. E. (2007). Elements of Shipping (8th ed.) New York: Routledge. 528p.

Brock, W., Dechect, W. \& Scheinkman, J. (1987). A test for independence based on the correlation dimension. Working Paper, Department of Economics, University of Wisconsin, Madison.

Buxton, I. L. (1991). The market for ship demolition. Maritime Policy \& Management, 18(2): 105-112. https://doi.org/ $\underline{10.1080 / 03088839100000034}$

Chuang, H-M., Lin, C-K., Chen, D-R. \& Chen, Y. S. (2013). Evolving MCDM applications using hybrid expertbased ISM and DEMATEL models: An example of sustainable ecotourism. The Scientific World Journal, 2013: 1-18. https://doi.org/10.1155/2013/751728

Dai, L., Hu, H., Chen, F. \& Zheng, J. (2015). The dynamics between new building ship price volatility and freight volatility in dry bulk shipping market. International Journal of Shipping and Transport Logistics, 7(4): 393406. https://doi.org/10.1504/IJSTL.2015.069666

Efes, K. Ö., Başer, S. Ö. \& Açık, A. (2019). Supply-demand interaction in the formation of freight rates: China's trade volume as demand side in the dry bulk market. Pomorstvo, 33(1): 46-55. https://doi.org/10.31217/ p.33.1.5

Engle, R. (1982). ARCH with estimates of variance of United Kingdom inflation. Econometrica, 50(4): 987-1007. https://doi.org/10.2307/1912773

Geman, H. (2009). Risk Management in Commodity Markets: From Shipping to Agriculturals and Energy (Vol. 445), England: John Wiley \& Sons. 320p.
Hatemi-J, A. (2012). Asymmetric causality tests with an application. Empirical Economics, 43(1): 447-456. https://doi.org/10.1007/s00181-011-0484-X

Hatemi-J, A. \& Uddin, G. S. (2012). Is the causal nexus of energy utilization and economic growth asymmetric in the US?. Economic Systems, 36(3): 461-469. https://doi.org/10.1016/j.ecosys.2011.10.005

Jugović, A., Komadina, N. \& Hadžić, A. (2015). Factors influencing the formation of freight rates on maritime shipping markets. Scientific Journal of Maritime Research, 29: 23-29.

Kagkarakis, N. D., Merikas, A. G. \& Merika, A. (2016). Modelling and forecasting the demolition market in shipping. Maritime Policy \& Management, 43(8): 10211035. https://doi.org/10.1080/03088839.2016.1185181

Karakitsos, E. \& Varnavides, L. (2014). Maritime Economics: A Macroeconomic Approach. London: Springer. 386p.

Kavussanos, M. G. (1997). The dynamics of time-varying volatilities in different size second-hand ship prices of the dry-cargo sector. Applied Economics, 29(4): 433-443. https://doi.org/10.1080/000368497326930

Kavussanos, M. G. \& Alizadeh, A. H. (2002). Efficient pricing of ships in the dry bulk sector of the shipping industry. Maritime Policy \& Management, 29(3): 303-330. https://doi.org/10.1080/03088830210132588

Knapp, S., Kumar, S. N. \& Remijn, A. B. (2008). Econometric analysis of the ship demolition market. Maritime Policy \& Management, 32(6): 1023-1036. https://doi.org/ $\underline{10.1080 / 03088839.2016 .1185181}$

Koopmans, T. C. (1939). Tanker Freight Rates and Tankship Building: An Analysis of Cyclical Fluctuations. Holland: Haarlem.

Langdana, F. K. (2009). Macroeconomic Policy: Demystifying Monetary and Fiscal Policy (2nd Ed.). US: Springer. $279 \mathrm{p}$.

Lawson, M. (2008). If Not Now, When? Three Actions the G20 Must Take Now to Protect the Word's Poor from The Economic Crisis and Build a New Political and Economic Governance System. London: Oxfam.

Lee, J. \& Strazicich, M. C. (2003). Minimum Lagrange Multiplier unit root test with two structural breaks. Review of Economics and Statistics, 85(4): 1082-1089. https://doi.org/10.1162/003465303772815961

Lee, J. \& Strazicich, M. C. (2013). Minimum LM unit root test with one structural break. Economics Bulletin, 33(4): 2483-2492.

Lun, Y. V., Lai, K. H. \& Cheng, T. E. (2010). Shipping and Logistics Management. London: Springer. 231p. 
Luthra, S., Garg, D. \& Haleem, A. (2015). An analysis of interactions among critical success factors to implement green supply chain management towards sustainability: An Indian perspective. Resources Policy, 46(1): 37-50. https://doi.org/10.1016/j.resourpol.2014.12.006

McConville J. (1999). Economics of Maritime Transport, Theory and Practice. London: Whiterby. 394p.

Metaxas, V. (1988). Principles of Maritime Economics. Athens: Papazisis.

Mikelis, N. E. (2007). A statistical overview of ship recycling. Proceedings of the International Symposium on Maritime Safety, Security \& Environmental Protection, Athens, Greece.

Narayan, P. K. \& Popp, S. (2010). A new unit root test with two structural breaks in level and slope at unknown time. Journal of Applied Statistics, 37: 1425-1438. https://doi.org/10.1080/02664760903039883

Pruyn, J. F. J., Van de Voorde, E., \& Meersman, H. (2011). Second hand vessel value estimation in maritime economics: A review of the past 20 years and the proposal of an elementary method. Maritime Economics \& Logistics, 13(2): 213-236. https://doi.org/10.1057/ $\underline{\text { mel.2011.6 }}$

Sage, A. P. (1977). Interpretive Structural Modeling: Methodology for Large-scale Systems. New York: McGraw-Hill. 445p.

Şahin, B., Gürgen, S., Ünver, B. \& Altin, I., (2018). Forecasting Baltic Dry Index by using an artificial neural network approach. Turkish Journal of Electrical Engineering \& Computer Sciences, 26(3): 1673-1684. https://doi.org/ 10.3906/elk-1706-155

Shahbaz, M., van Hoang, T. H., Mahalik, M. K. \& Roubaud, D. (2017). Energy consumption, financial development and economic growth in India: New evidence from a nonlinear and asymmetric analysis. Energy Economics, 63: 199-212. https://doi.org/10.1016/j.eneco.2017.01. $\underline{023}$

Stopford, M. (2009). Maritime Economics (3rd ed.). New York: Routledge. $815 \mathrm{p}$.

Strandenes, S. P. (2012). Maritime freight markets (pp. 107120). In Walley, T.K. (Ed.), The Blackwell Companion to Maritime Economics. UK: Wiley-Blackwell. 735p.

Tar1, R. and İnce, M. R. (2019). Analysis of global trade volume within the scope of maritime transport market: Markov regime switching model. Kocaeli Üniversitesi Sosyal Bilimler Dergisi, 37: 1-20. https://doi.org/10.35343/ $\underline{\text { kosbed.581404 }}$
Toda, H. Y. \& Yamamoto, T. (1995). Statistical inference in Vector Autoregressions with Possibly Integrated Processes. Journal of Econometrics, 66: 225-250. https://doi.org/10.1016/0304-4076(94)01616-8

Tsolakis, S. (2005). Econometric analysis of bulk shipping markets: Implications for investment strategies and financial decision-making. Ph.D. Thesis. Erasmus University, Rotterdam.

Tugcu, C. T. \& Topcu, M. (2018). Total, renewable and nonrenewable energy consumption and economic growth: revisiting the issue with an asymmetric point of view. Energy, 152: 64-74. https://doi.org/10.1016/j.energy. 2018.03.128

Tugcu, C. T., Ozturk, I. \& Aslan, A. (2012). Renewable and nonrenewable energy consumption and economic growth relationship revisited: evidence from G7 countries. Energy Economics, 34(6): 1942-1950. https://doi.org/ 10.1016/j.eneco.2012.08.021

Tunç, M. \& Açık, A. (2019). The impact of steel price on ship demolition prices: Evidence from heterogeneous panel of developing countries. Sosyoekonomi, 27(42): 227-240. https://doi.org/10.17233/sosyoekonomi.2019.04.12

Tvedt, J. (2003). A new perspective on price dynamics of the dry bulk market. Maritime Policy \& Management, 30(3): 221-230. https://doi.org/10.1080/0308883032000133413

Umar, M. \& Dahalan, J. (2016). An application of asymmetric Toda-Yamamoto causality on exchange rate-inflation differentials in emerging economies. International Journal of Economics and Financial Issues, 6(2): 420426.

UN. (2009). United Nations. World Economic Situation and Prospects 2009 (World Economic and Social Survey. Supplement). New York. 33p.

Yudatama, U., Hidayanto, A. N. \& Nazief, B. A. A. (2018). Approach using interpretive structural model (ISM) to determine key sub-factors at factors: Benefits, risk reductions, opportunities and obstacles in awareness IT Governance. Journal of Theoretical and Applied Information Technology, 96(16): 5537-5549.

Zivot, E. \& Andrews, D. W. K. (1992). Further evidence on the Great Crash, the oil-price shock, and the unit-root hypothesis. Journal of Business \& Economic Statistics, 20(1): 25-44. https://doi.org/10.1080/07350015.1992. $\underline{10509904}$ 